\title{
FAKTOR-FAKTOR YANG BERPENGARUH TERHADAP MINAT BERWIRAUSAHA MAHASISWA \\ (Studi Kasus Pada Program Studi Statistika Fakultas MIPA, Fakultas Tekhnologi Informasi Dan Komunikasi Universitas Mulawarman Dan Politeknik Pertanian Negeri Samarinda)
}

\author{
Ita Merni Patulak \\ Politeknik Pertanian Negeri Samarinda \\ Email:mernivania@gmail.com
}

\begin{abstract}
This study aims to determine the factors that affect student interest in entrepreneurship. These factors include Entrepreneurship Class Matter (X1), Training / Courses Entrepreneurship (X2) and demographic factors (X3). The study involved a sample of 115 people, comprising as many as 50 people at the Faculty of Mathematics and Natural Sciences Statistics Mulawarman University, 40 people at the Faculty of ICT Mulawarman University and Samarinda State Agricultural Polytechnic students on study programs Agricultural of Technology many as 25 people. The respondents were students who take courses in Entrepreneurship academic year 2013/2014. The results of the study indicate factors lecture material (X1), Training / Training Course (X2) and Demographic Factors (X3) have a significant effect on the dependent variable (Y) is the interest of students in entrepreneurship, it can be seen by $\mathrm{F}$ test at testing the hypothesis that calculated $F$ value of 27.688> $F$ table 2.50, with 0,000 significant smaller than 0.05 . Based on the partial test, $t$ value of each variable obtained dominant variables are $\mathrm{X} 1$ (Material Class Entrepreneurship) with the largest $\mathrm{t}$ value, a smallest level of significant. Shows that the improvements in the lecture material taught by lecturer of entrepreneurship in the form of theory and practice, will be the spirit of students to be self-employed or self-employed can prepare for the future after graduation.
\end{abstract}

Keywords: student interest in entrepreneurship, lecture material entrepreneurship, training / courses, demographic factors.

Abstrak: Penelitian ini bertujuan untuk mengetahui faktor-faktor yang mempengaruhi minat mahasiswa berwirausaha. Faktor-faktor tersebut mencakup Materi Perkuliahan Kewirausahaan (X1), Pelatihan/Kursus Kewirausahaan (X2) dan Faktor Demografis (X3). Penelitian ini melibatkan sampel 115 orang dengan perincian sebanyak 50 orang pada Prodi Statistik Fakultas Mipa Unmul, 40 orang pada Fakultas TIK Unmul, dan mahasiswa Politeknik Pertanian Negeri Samarinda pada prodi TPHP dan prodi THH sebanyak 25 orang. Responden tersebut adalah mahasiswa yang mengambil mata kuliah Kewirausahaan pada semester ganjil tahun Akademik 2013 / 2014.Hasil-hasil penelitian menunjukkan faktor-faktor materi perkuliahan (X1), Pelatihan / Kursus Pelatihan (X2) dan Faktor Demografis (X3) berpengaruh signifikan terhadap variabel terikat (Y) yaitu minat mahasiswa berwirausaha, ini dapat dilihat berdasarkan uji $\mathrm{F}$ pada pengujian hipotesis dimana nilai $\mathrm{F}$ hitung sebesar 27,688 > F tabel 2,50, dengan signikansi 0,000 lebih kecil daripada 0,05.Berdasarkan uji parsial, nilai t hitung masingmasing variabel diperoleh variabel dominan adalah X1 (Materi Perkuliahan 
Kewirausahaan) dengan nilai $\mathrm{t}$ hitung terbesar, tingkat signifikan terkecil.Hal ini menunjukkan bahwa dengan semakin baiknya materi perkuliahan kewirausahaan yang diajarkan oleh dosen baik dalam bentuk teori maupun praktek, akan memacu semangat mahasiswa untuk bisa berwirausaha atau mempersiapkan diri untuk dapat berwirausaha kelak setelah lulus.

Kata Kunci: Minat mahasiswa berwirausaha, materi perkuliahan kewirausahaan, pelatihan/kursus, faktor demografis.

\section{PENDAHULUAN}

Menumbuhkan jiwa kewirausahaan para mahasiswa perguruan tinggi merupakansalah satu alternatif jalan keluar untuk mengurangi tingkat pengangguran, karena para sarjana diharapkan dapat menjadi wirausahawan muda terdidik yang mampu merintis usahanya sendiri. Jumlah wirausahawan muda di Indonesia masih tertinggal jauh dibandingkan negara-negara maju seperti Amerika maupun Singapura. Padahal secara konsensus, sebuah negara agar bisa majuidealnya memiliki wirausahawan sebanyak 5\% dari total penduduknya yang dapat menjadi keunggulan daya saing bangsa.

Menyikapi persaingan dunia bisnis masa kini dan masa depan yang lebih mengandalkan pada knowledge dan intelectual capital, maka agar dapat menjadi daya saing bangsa, pengembangan wirausahawan muda perlu diarahkan pada kelompok orang muda terdidik (intelektual). Mahasiswa yang adalah calon lulusan perguruan tinggi perlu didorong dan ditumbuhkan niat mereka untuk berwirausaha (Interpreneurial intention).

Pakar wirausaha Zimmerer (2002:12), menyatakan bahwa salah satu faktor pendorong pertumbuhan kewirausahaan disuatu negara terletak pada peranan Perguruan Tinggi melalui penyelenggaraan pendidikan kewirausahaan. Pihak Perguruan Tinggi bertanggung jawab dalam mendidik dan memberikan kemampuan wirausaha kepada para lulusannya dan memberikan motivasi untuk berani memilih berwirausaha sebagai karir mereka. Pihak perguruan tinggi perlu menerapkan pola pembelajaran kewirausahaan yang kongkrit berdasar masukan empiris untuk membekali mahasiswa dengan pengetahuan yang bermakna agar dapat mendorong semangat mahasiswa untuk berwirausaha (Yohnson, 2003). Persoalannya bagaimana menumbuhkan motivasi berwirausaha di kalangan mahasiswa dan faktor-faktor apa yang berpengaruh terhadap motivasi atau niat mahasiswa untuk memilih karir berwirausaha setelah mereka lulus sarjana, masih menjadi pertanyaan dan memerlukan penelaahan lebih jauh.

Kewirausahaan adalah keberanian, keutamaan, serta keperkasaan dalam memenuhi kebutuhan serta memecahkan permasalahan hidup dengan kekuatan yang ada pada diri sendiri. Kewirausahaan pada zaman dulu tidak perlu dipelajari, karena merupakan urusan langsung di lapangan.Tetapi sejak awal abad ke 20 kewirausahaan diperkenalkan di beberapa negara, seperti di Belanda dan Jerman. Sejak itu kewirausahaan bukan merupakan bakat bawaan saja sejak lahir dan urusan langsung di lapangan, tetapi kewirausahaan merupakan sebuah ilmu yang harus dipelajari.

Zimmerer (1996) mengatakan dalam konteks bisnis kewirausahaan adalah hasil dari suatu disiplin, proses sistematis dalam menerapkan kreatifitas dan keinovasian untuk memenuhi dan menangkap peluang yang ada di pasar. Sedang Joseph Shumpeter (1986), mengatakan bahwa seorang entrepreneur adalah seorang yang inovator dan 
mengembangkan tekhnologi, entrepreneur adalah seorang yang energik dan membatasi resiko.

Dari sejumlah penelitian yang telah dilakukan terhadap motivasi seseorang untuk berwirausaha, dapat disimpulkan bahwa niat kewirausahaan seseorang dipengaruhi sejumlah faktor yang dapat dilihat dalam suatu kerangka yang melibatkan berbagai faktor internal, faktor eksternal dan faktor kontekstual (Johnson, 1990; Stewart, 1998). Faktor internal berasal dari dalam diri wirausahawan dapat berupa karakter sifat, maupun faktor sosiodemografi seperti umur, jenis kelamin, pengalaman kerja, latar belakang keluarga dan lain-lain yang dapat mempengaruhi perilaku kewirausahaan seseorang.Faktor eksternal berasal dari luar diri pelaku entrepreneur yang dapat berupa unsur dari lingkungan sekitar dan kondisi kontekstual.

Temuan dari berbagai studi tentang berbagai faktor yang dapat membentuk perilaku kewirausahaan seseorang semakin jelas memperlihatkan bahwa kewirausahaan seseorang dapat dipelajari dan dibentuk seperti yang disampaikan Johnson (1990). Untuk itu sejumlah atribut personality seperti adanya kebutuhan berprestasi, tingginya kreativitas dan inovasi, ikut berperan dalam membentuk niat orang untuk berwirausaha (Gorman, 1997; Nishanta, 2008). Demikian juga faktor sikap seseorang dalam memandang kegiatan berwirausaha juga dipercayai akan membentuk niat kewirausahaan (Azjen \& Fishbein, 1985 dalam Gurbuz \& Aykol, 2008). Sedangkan faktor kontekstual yang cukup mendapat perhatian peneliti adalah dukungan akademik, dukungan sosial dan kondisi lingkungan usaha.

Orang-orang yang menempuh pendidikan dalam sebuah Negara yang semakin maju, akanada yang mengalami proses meleset dari harapan, yaitu pada saat lulus dari pendidikannya, mengalami fase menjadi pengangguran karena tidak langsung memperoleh pekerjaan. Dalam kondisi tersebut, maka semakin dirasakan pentingnya dunia wirausaha. Pembangunan akan lebih berhasil jika ditunjang oleh wirausahawan yang dapat membuka lapangan kerja karena kemampuan pemerintah sangat terbatas. Pemerintah tidak akan mampu menggarap semua aspek pembangunan karena sangat banyak membutuhkan anggaran belanja, personalia, dan pengawasan. Oleh sebab itu, wirausaha merupakan potensi penbangunan, baik dalam jumlah maupun dalam mutu wirausaha itu sendiri. Sekarang ini kita menghadapi kenyataan bahwa jumlah dan mutu wirausahawan Indonesia masih kurang sehingga persoalan pembangunan wirausaha Indonesia merupakan persoalan mendesak bagi suksesnya pembangunan.

Politeknik Pertanian Negeri Samarinda, sebagai salah satu institusi pendidikan negeri yang ada di Indonesia, juga mengajarkan bahkan kini banyak memberikan pelatihan tentang kewirausahaan pada semua Jurusan dan Program Studi yang ada di dalam Perguruan tinggi tersebut. Demikian juga pada Program Studi Statistik Fakultas MIPA Universitas Mulawarman (Unmul) dan Fakultas Teknologi Informasi dan Komunikasi (TIK) Unmul juga memberikan mata kuliah Kewirausahaan bagi mahasiswanya.

Hampir setiap tahunnya dilakukan perbaikan-perbaikan terhadap materi yang diajarkan, baik dalam bentuk SAP, GBPP, maupun dalam bentuk modul yang diberikan kepada mahasiswa. Dan sejak tahun 2009 dengan adanya hibah dari Dirjen Dikti diberikan modal bagi para mahasiswa dalam bentuk kegiatan Program Mahasiswa Wirausaha (PMW) yang disalurkan kepada kelompok mahasiswa dengan syarat proposal usahanya memenangkan kompetisi di Perguruan tingginya. Hal ini ditujukan agar semakin tumbuhnya jiwa wirausaha dalam diri mahasiswa. Berdasarkan latar belakang di atas perlu diadakan pengamatan bahkan penelitian terhadap mahasiswa, faktor-faktor apa saja yang 
berpengaruh terhadap tertanamnya bahkan tumbuhnyan jiwa wirausaha dalam diri mahasiswa pada beberapa Perguruan Tinggi tersebut dengan menggunakan 3 Variabel bebas dan 1 variabel terikat yaitu:

$\mathrm{Y}=$ Minat Berwirausaha; X1 = Materi Perkuliahan Kewirausahaan; X2= Pelatihan/Kursus Kewirausahaan; X3 = Faktor Demografis.

\section{KAJIAN TEORI}

Menurut Dan Steinhoff dan John F.Burges (1993), "Pada hakikatnya wirausaha adalah orang yang mengorganisir, mengelolah, dan berani menanggung resiko untuk menciptakan usaha baru". Orang yang berwirausaha harus memiliki kemampuan untuk: (1) Menemukan dan mengevaluasi peluang; (2) Mengumpulkan kekuatan yang berupa sumber-sumber daya yang diperlukan; (3) Berusaha bertindak untuk mengambil keuntungan dari peluang-peluang itu.

Menurut Prof. Buchari Alma, secara umum dapat dikatakan, bahwa manusia yang berwirausaha adalah orang yang memiliki ciri-ciri dan potensi sebagai berikut: (1) Memiliki potensi dan motivasi yang besar untuk berprestasi; (2) Mampu menolong dirinya sendiri untuk mengatasi permasalahan hidupnya dalam kondisi dan situasi yang bagaimanapun; (3) Tanggap terhadap kekuatan yang dimilikinya dan menggunakan kekuatan yang ada pada dirinya untuk memenuhi kebutuhan hidupnya; (4) Tidak suka mengharapkan uluran tangan pihak lain, dan tidak bergantung pada alam sekitarnya; (5) Wirausaha tidak mudah menyerah, justru selalu berupaya untuk bertahan dari tekanan seperti persaingan, dan berusaha untuk menundukkan tekanan tersebut

Faktor demografis (gender, latar belakang pendidikan orang tua, dan pengalaman bekerja) dapat mempengaruhi pilihan karir menjadiwirausahawan.Kecenderungan seseorang untuk melakukan atau tidak melakukan sesuatu, seperti memilih kewirausahaan sebagai pilihan karir, dapat diprediksi oleh Teori Perilaku Terencana (Theory of Planned Behavior-TPB) yang dikemukakan oleh Hannes Leroy et all (2009). TPB menggunakan tiga pilar sebagai anteseden dari intensi, yaitu sikap terhadap perilaku, norma subyektif, dan persepsi mengenai kemampuan mengendalikan segala sesuatu yang mempengaruhi apabila hendak melakukan perilaku tersebut.

\section{METODE}

Penelitian ini pertama kali dilakukan di Poltanesa Tahun 2009 kemudian berkelanjutan pada Tahun 2013-2014 dengan mengembangkan penelitian untuk mahasiswa yang mengambil mata kuliah Kewirausahaan yang Poltanesa Program Studi (Prodi) Teknologi Pengolahan Hasil Perkebunan (TPHP) dan mahasiswa Prodi Tekhnologi Hasil Hutan (THH), kemudian pada mahasiswa Prodi Statistik Fakultas MIPA Unmul dan mahasiswa Fakultas TIK Unmul.

Populasi dalam penelitian ini, yaitu mahasiswa yang menempuh mata kuliah Kewirausahaan pada semester ganjil tahun akademik 2013/2014 dengan total responden 115 orang dengan perincian sebanyak 50 orang pada Prodi Statistik Fakultas Mipa Unmul, 40 orang pada Fakultas TIK Unmul, dan mahasiswa Politeknik Pertanian Negeri Samarinda pada prodi TPHP dan prodi THH sebanyak 25 orang. Alat-alat yang digunakan dalam penelitian ini adalah: Kuisioner dalam bentuk pertanyaan isian dan pertanyaan pilihan, yang dibagikan kepada mahasiswa, kamera untuk memotret kegiatan pembagian 
kuisioner dan pengisian kuisioner sebagai bukti kegiatan penelitian, komputer, software SPSS yang digunakan untuk pengolahan data hasil isian kuisioner para responden.

\section{HASIL DAN PEMBAHASAN}

Identifikasi Variabel Penelitian. Variabel-variabel yang digunakan dalam penelitian ini terdiri dari 1 variabel terikat yaitu Minat Berwirausaha dan 3 variabel bebas yaitu X1 Materi Perkuliahan Kewirausahaan, X2 Pelatihan / Kursus Kewirausahaan, X3 Faktor Demografis. Dari pengujian validitas instrumen pengukur yang dilakukan dengan memperhatikan nilai communalities sama atau lebih besar dari 0,5 dan faktor loading untuk tiap-tiap item pertanyaan sama atau lebih besar dari 0,5.Berdasarkan kriteria diatas, berikut merupakan hasil perhitungan dari masing-masing item pertanyaan yang dimasukan dalam tabel-tabel.

Tabel 1. Validitas Indikator Materi Perkuliahan Kewirausahaan (X1)

\begin{tabular}{cccc}
\hline Indikator & Factor Loading & Communalities & Keterangan \\
\hline X1.1 & 0,829 & 0,729 & Valid \\
X1.2 & 0,554 & 0,522 & Valid \\
X1.3 & 0,855 & 0,795 & Valid \\
\hline
\end{tabular}

Sumber: Data diolah Tahun 2014

Berdasarkan Tabel di atas, maka seluruh item pertanyaan untuk variabel X1, menunjukkan angka communalities dan faktor loading yang $>0,5$, sehingga dapat dipertahankan untuk dianalisis lebih lanjut dalam penelitian ini.

Tabel 2. Validitas Indikator Pelatihan/Kursus Kewirausahaan (X2)

\begin{tabular}{cccc}
\hline Indikator & Factor Loading & Communalities & Keterangan \\
\hline X2.1 & 0,912 & 0,886 & Valid \\
X2.2 & 0,551 & 0,696 & Valid \\
X2.3 & 0,751 & 0,763 & Valid \\
\hline
\end{tabular}

Sumber : Data diolah Tahun 2014

Berdasarkan Tabel diatas, maka seluruh item pertanyaan untuk variabel X2menunjukkan angka communalities dan factor loading yang $>0,5$, sehingga dapat dipertahankan untuk dianalisis lebih lanjut dalam penelitian ini.

Tabel 3. Validitas Indikator Faktor Demografis (X3)

\begin{tabular}{cccc}
\hline Indikator & Factor Loading & Communalities & Keterangan \\
\hline X3.1 & 0,911 & 0,871 & Valid \\
X3.2 & 0,778 & 0,626 & Valid \\
X3.3 & 0,710 & 0,687 & Valid \\
\hline
\end{tabular}

Sumber: Data diolah Tahun 2014

Berdasarkan Tabel diatas, maka seluruh item pertanyaan untuk variabel X3menunjukkan angka communalities dan factor loading yang $>0,5$, sehingga dapat dipertahankan untuk dianalisis lebih lanjut dalam penelitian ini. 
Tabel 4. Validitas Indikator Minat Berwirausaha (Y)

\begin{tabular}{cccc}
\hline Indikator & Factor Loading & Communalities & Keterangan \\
\hline Y1 & 0,854 & 0,770 & Valid \\
Y2 & 0,714 & 0,634 & Valid \\
Y3 & 0,641 & 0,665 & Valid \\
\hline
\end{tabular}

Sumber : Data diolah Tahun 2014

Berdasarkan Tabel diatas, maka seluruh item pertanyaan untuk variabel Minat Berwirausaha(Y)menunjukkan angka communalities dan factor loading yang $>0,5$, sehingga dapat dipertahankan untuk dianalisis lebih lanjut dalam penelitian ini.

Uji Reliabilitas. Uji reliabilitas digunakan untuk melihat apakah respon atau tanggapan dari responden akan menghasilkan nilai yang sama jika dilakukan dalam waktu dan tempat yang berbeda. Adapun tabel dari kriteria reliabilitas dapat dilihat dalam tabel sebagai berikut:

Tabel 5. Interprestasi Reliabilitas ( Nilai R)

\begin{tabular}{ll}
\hline R Alpha & Interprestasi \\
\hline $0,800-1,000$ & Tinggi \\
$0,600-0,800$ & Cukup \\
$0,400_{-} 0,600$ & Agak Rendah \\
$0,200_{-} 0,400$ & Rendah \\
$0,000_{-} 0,200$ & Sangat Rendah (Tidak Berkorelasi) \\
\hline
\end{tabular}

Sumber: Malhotra, Marketing Research: An AppliedOrientation; Prentice Hall, Inc., Fourth Edition, Engelwood Cliffs, New Jersey

Setelah diadakan perhitungan dengan menggunakan SPSS versi 16, maka diperoleh hasil koefisien korelasi (Cronboach's Alpha) seperti pada tabel berikut ini:

Tabel 6. Hasil Uji Reliabilitas Kuesioner

\begin{tabular}{clcc}
\hline No. & \multicolumn{1}{c}{ Variabel } & R-Alpha & Keputusan \\
\hline 1. & Materi Perkuliahan Kkewirausahaan & 0,7386 & Reliabel \\
2. & Pelatihan/Kursus Kewirausahaan(X2) & 0,7167 & Reliabel \\
3. & Faktor Demografis (X3) & 0,7021 & Reliabel \\
\hline
\end{tabular}

Sumber : Data diolah Tahun 2014

Dilihat dari nilai $\mathrm{R}$ Alpha pada tiap-tiap variabel, menunjukkan nilai lebih lebih besar dari 0,6 maka semua variabel dapat dikatakan valid dan reliabel. Sedangkan untuk nilai Cronbach's Alpha untuk instrument secara keseluruhan diperoleh sebesar 0,6533 dimana nilainya positif dan lebih besar dari $r$ tabel $(0,246)$. Sehingga dapat dikatakan reliabel dan hal ini menunjukkan adanya konsistensi.

Uji Autokorelasi. Dari Tabel summary diperoleh nilai Durbin-Watson 1,627. Hal ini menandakan tidak ada autokorelasi antar variabel. Menurut Alqhi Fahri dalam Regresi Berganda, syarat autokorelasi, yaitu: 
Tabel 7. Tabel Autokorelasi Durbin-Watson

\begin{tabular}{cc}
\hline$<1,10$ & Ada Autokorelasi \\
$1,10-1,54$ & Tanpa Kesimpulan \\
$1,55-2,46$ & Tidak Ada Autokorelasi \\
$2,47-2,90$ & Tanpa Kesimpulan \\
$>2,90$ & Ada Autokorelasi \\
\hline
\end{tabular}

Sumber: Alqhi Fahri, Regresi Berganda

Berdasarkan pengolahan data dengan menggunakan software SPSS 16.0 diperoleh sebagai berikut:

Model Summary ${ }^{\mathrm{b}}$

\begin{tabular}{cccccc}
\hline Model & $\mathrm{R}$ & R Square & $\begin{array}{c}\text { Adjusted R } \\
\text { Square }\end{array}$ & $\begin{array}{c}\text { Std. Error of the } \\
\text { Estimate }\end{array}$ & Durbin-Watson \\
\hline 1 &, $585^{\mathrm{a}}$ &, 342 &, 330 & 1,62379 & 1,627 \\
\hline
\end{tabular}

a. Predictors: (Constant), X3, X1, X2

b. Dependent Variabel: Y

Multikolinearitas. Dari semua variabel X1,X2,...X5 menunjukkan bahwa nilai Variance Inflation Factor (VIF) memperlihatkan nilai yang < 10 sehingga dapat dikatakan tidak terjadi multikolinearitas.

\begin{tabular}{|c|c|c|c|c|c|c|c|}
\hline \multicolumn{8}{|c|}{ Coefficients $^{\mathrm{a}}$} \\
\hline \multirow[b]{2}{*}{ Model } & \multicolumn{2}{|c|}{$\begin{array}{l}\text { Unstandardized } \\
\text { Coefficients }\end{array}$} & \multirow{2}{*}{$\begin{array}{c}\begin{array}{c}\text { Standardized } \\
\text { Coefficients }\end{array} \\
\text { Beta }\end{array}$} & \multirow[t]{2}{*}{$\mathrm{t}$} & \multirow[t]{2}{*}{ Sig. } & \multicolumn{2}{|c|}{$\begin{array}{l}\text { Collinearity } \\
\text { Statistics }\end{array}$} \\
\hline & $\mathrm{B}$ & $\begin{array}{l}\text { Std. } \\
\text { Error }\end{array}$ & & & & Tolerance & VIF \\
\hline 1 (Constant) &,- 509 & 1,026 & &,- 496 & ,620 & & \\
\hline $\mathrm{X} 1$ &, 160 &, 061 & , 139 & 2,642 & ,009 & ,896 & 1,116 \\
\hline $\mathrm{X} 2$ & 156 &, 067 & 131 & 2,338 & ,020 & ,784 & 1,275 \\
\hline $\mathrm{X} 3$ &, 150 &, 066 &, 126 & 2,270 &, 024 & ,807 & 1,239 \\
\hline
\end{tabular}

a. Dependent Variabel: Y

Heteroskedastisitas. Dari grafik Scatterplot terlihat bahwa titik-titik menyebar secara acak, tidak membentuk pola tertentu yang jelas dan tersebar baik diatas maupun di bawah angka 0 pada sumbu Y. Hal ini berarti tidak terjadi heteroskedastisitas pada model regresi, sehingga model regresi layak untuk digunakan.

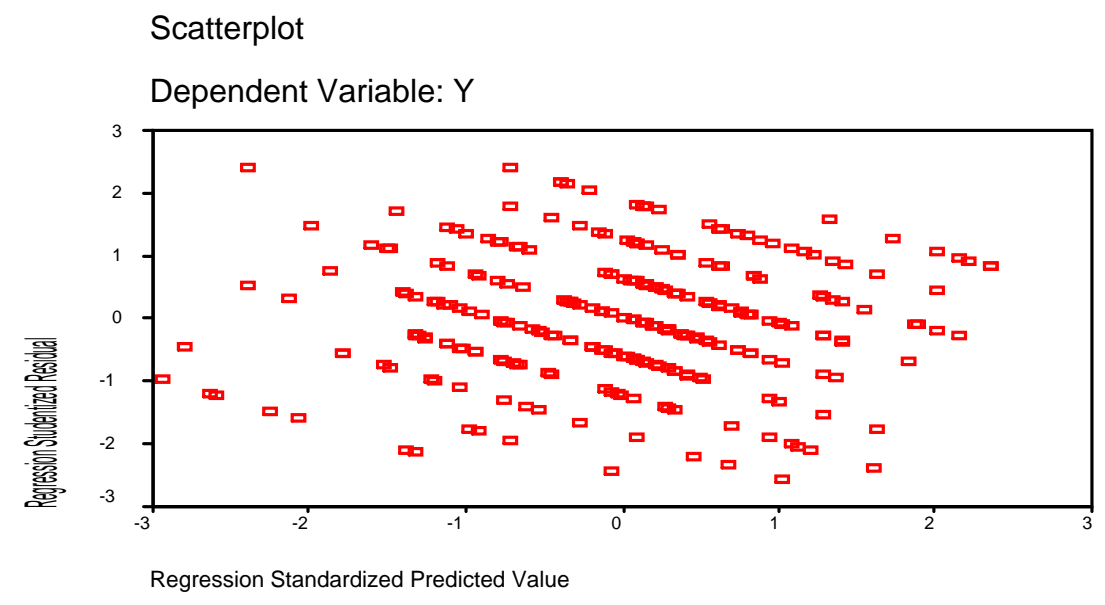


Normalitas. Dari grafik Normal P-P Plot of Regresion Standardized Residual terlihat bahwa titik-titik menyebar di sekitar garis diagonal dan mengikuti garis normal. Hal ini berarti, asumsi normalitas terpenuhi.

Normal P-P Plot of Regression Standardized Residual

Dependent Variable: $Y$

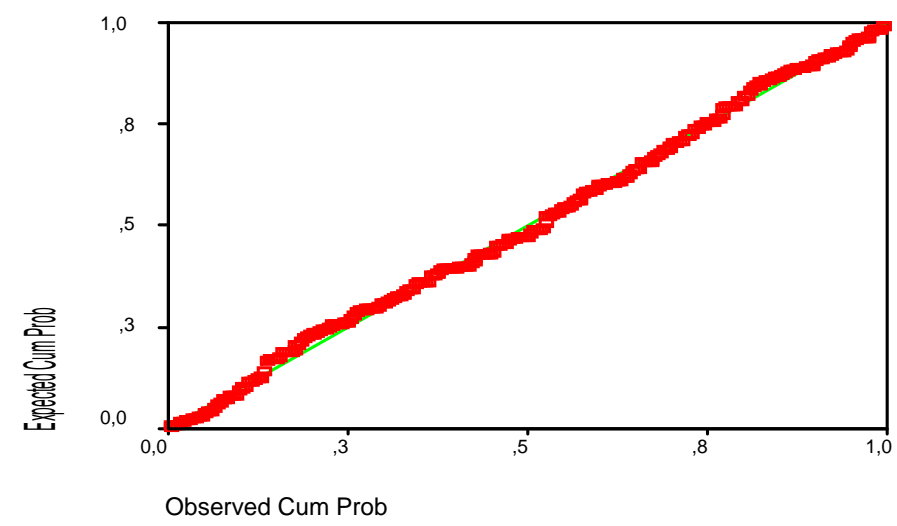

Setelah dilakukan berbagai pengujian dengan bantuan program SPSS 16.0 diperoleh persamaan regresi sebagai berikut:

\section{Coefficients $^{\mathrm{a}}$}

\begin{tabular}{|c|c|c|c|c|c|c|c|}
\hline \multirow[b]{2}{*}{ Model } & \multicolumn{2}{|c|}{$\begin{array}{l}\text { Unstandardized } \\
\text { Coefficients }\end{array}$} & \multirow{2}{*}{$\begin{array}{c}\text { Standardized } \\
\text { Coefficients } \\
\text { Beta }\end{array}$} & \multirow[t]{2}{*}{$\mathrm{t}$} & \multirow[t]{2}{*}{ Sig. } & \multicolumn{2}{|c|}{$\begin{array}{l}\text { Collinearity } \\
\text { Statistics }\end{array}$} \\
\hline & B & $\begin{array}{l}\text { Std. } \\
\text { Error }\end{array}$ & & & & Tolerance & VIF \\
\hline 1 (Constant) &,- 509 & 1,026 & & 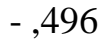 & ,620 & & \\
\hline $\mathrm{X} 1$ & , 160 & ,061 & 139 & 2,642 & ,009 & 896 & 1,116 \\
\hline $\mathrm{X} 2$ & , 156 & ,067 & 131 & 2,338 & ,020 & ,784 & 1,275 \\
\hline X3 & , 150 & ,066 & , 126 & 2,270 & ,024 & 807 & 1,239 \\
\hline
\end{tabular}

Persamaannya:

$$
\mathrm{Y}=-0,509+0,160 \mathrm{X} 1+0,156 \mathrm{X} 2+0,150 \mathrm{X} 3
$$

Keterangan: $\mathrm{Y}=$ Minat Berwirausaha; $\mathrm{X} 1=$ Materi Perkuliahan Kewirausahaan; $\mathrm{X} 2=$ Pelatihan/Kursus Kewirausahaan; X3 = Faktor Demografis.

Berdasarkan persamaan regresi yang diperoleh, dapat dijelaskan mengenai koefisiennya, sebagai berikut:

1. Nilai konstanta menunjukan besarnya Minat Mahasiswa Berwirausaha pada beberapa Perguruan Tinggi (Y) apabila Materi Perkuliahan Kewirausahaan (X1), Pelatihan/Kursus Kewirausahaan (X2), Faktor Demografis (X3) sebesar nol (0) maka besarnya Minat Mahasiswa Berwirausaha (Y) akan menjadi buruk, ini ditandai dengan nilai $-0,509$. Ini berarti bila institusi pendidikan tinggi tersebut tidak melakukan atau tidak didukung oleh ke-3 variabel bebas tersebut dalam menumbuhkan minat berwirausaha mahasiswa, maka para mahasiswatidak tergali semangatnya dalam berwirausaha. 
2. Koefisien regresi variabel X1 sebesar 0,160 berarti bahwa jika terjadi perubahan ke arah positif atau peningkatan dari Materi Perkuliahan, maka minat mahasiswa berwirausaha (Y) akan berubah secara positif pula. Begitu pula sebaliknya, jika terjadi perubahan X1kearah negatif, maka variabel terikat (Y) akan berubah secara negatif atau menurun.

Nilai 0,160 berarti bahwa jika terjadi perubahan pada variabel $\mathrm{X} 1$ sebesar 1 satuan maka variabel $\mathrm{Y}$ akan berubah sebesar 0,160 satuan, artinya apabila Materi Perkuliahan Tentang Kewirausahaan ditingkatkan mutunya, maka Minat mahasiswa berwirausaha (Y) akan naik, begitu pula apabila X1 menurun, maka variabel $Y$ juga akan turun, dengan asumsi X2 dan X3 tetap (tidak mengalami perubahan). Demikian juga pada variabel X2 dan X3.

Berdasarkan koefisien regresi yang diperoleh, terlihat bahwa koefisien regresi terbesar terdapat pada variabel X1yaitu Materi Perkuliahan Kewirausahaansebesar 0,160. Ini berarti bahwa Minat Mahasiswa Dalam Berwirausaha di beberapa perguruan tinggi tersebutdominan dipengaruhi oleh Materi Perkuliahan yang mereka terima. Dengan kata lain, apabila kita ingin meningkatkan Minat mahasiswa berwirausaha, maka hal-hal yang berhubungan dengan Materi Perkuliahan (X1), sangat perlu diperhatikan dan diutamakan.

Uji Kelayakan (Validitas Model)

Model Summary ${ }^{\mathrm{b}}$

\begin{tabular}{cccccc}
\hline Model & $\mathrm{R}$ & $\mathrm{R}$ Square & $\begin{array}{c}\text { Adjusted R } \\
\text { Square }\end{array}$ & $\begin{array}{c}\text { Std. Error of the } \\
\text { Estimate }\end{array}$ & Durbin Watson \\
\hline 1 &, $585^{\mathrm{a}}$ &, 342 &, 330 & 1,62379 & 1,627 \\
\hline
\end{tabular}

a. Predictors: (Constant) X3, X1, X2

b. Dependent Variabel: Y

Dari model persamaan regresi yang telah terbentuk diperoleh nilai koefisien korelasi (Multiple R) secara menyeluruh sebesar 0,585 atau 58,5\% yang artinya hubungan antara variabel Materi Perkuliahan (X1), Pelatihan/Kursus Kewirausahaan (X2), Faktor Demografis (X3) sebagai variabel bebas dengan Minat mahasiswa berwirausaha (Y) sebagai variabel terikat, adalah positif dan cukup kuat. Ini berarti apabila pihak Perguruan Tinggi memperhatikan ke-3 variabel diatas, maka Minat berwirausaha mahasiswa akan semakin baik/meningkat.

Sedangkan nilai koefisien determinasi $\left(\mathrm{R}^{2}\right)$ adalah 0,342. Ini berarti sebesar 34,2\% proporsi keragaman Minat berwirausaha mahasiswa(Y) yang dapat dijelaskan oleh variabel X1, X2 dan X3, sedangkan 65,8 \% lainnya dijelaskan oleh variabel lain di luar Ke-3 variabel bebas tersebut yang tidak diteliti dalam penelitian ini.

\begin{tabular}{ccccccc}
\multicolumn{8}{c}{ ANOVA $^{\mathrm{b}}$} \\
\hline \multirow{2}{*}{ Model } & Sum of & df & Mean Square & F & Sig. \\
& Squares & & & & \\
\hline 1 & Regression & 365,019 & 5 & 73,004 & 27,688 &, $000^{\mathrm{a}}$ \\
& Residual & 701,360 & 47 & 2,637 & & \\
& Total & 1066,379 & 52 & & & \\
\hline
\end{tabular}

a. Predictors: (Contant), X3, X1, X2

b. Dependent Variabel: $Y$ 
Berdasarkan uji kelayakan (validitas model) dengan menggunakan nilai $\mathrm{F}$ hitung yang diperoleh sebesar 27,688 > F tabel 2,50, dengan signikansi 0,000 lebih kecil daripada 0,05 maka dapat dikatakan bahwa model persamaan tersebut layak digunakan dan secara keseluruhan variabel-variabel bebasnya mempunyai pengaruh yang signifikan terhadap Minat berwirausaha mahasiswa pada ke 4 Program studibeberapa Perguruan Tinggi di Samarinda tersebut. Jadi berdasarkan pengujian Anova, dapat diketahui bahwa variabel $\mathrm{X} 1$, $\mathrm{X} 2$ dan $\mathrm{X}$ 3, memiliki pengaruh yang nyata terhadap Minat berwirausaha mahasiswa(Y).

Berdasarkan hasil perhitungan dengan menggunakan bantuan program SPSS, nilai Fratio yang diperoleh adalah 27,688 (Tabel Anova) dengan signifikansi 0,000 sehingga dapat disimpulkan $\mathrm{H}_{1}$ diterima pada tingkat signifikansi 0,05. Jadi Hipotesis 1 yang menyatakan bahwa Materi Perkuliahan Kewirausahaan (X1), Pelatihan/Kursus Kewirausahaan (X2), Faktor Demografis (X3), memiliki pengaruh yang nyata terhadap Minat berwirausaha mahasiswa(Y), dapat diterima.

Pengujian Hipotesis Koefisien Regresi Secara Parsial (Uji t)

Tabel 8. Coefficients ${ }^{\mathrm{a}}$

\begin{tabular}{|c|c|c|c|c|c|c|c|}
\hline \multirow[b]{2}{*}{ Model } & \multicolumn{2}{|c|}{$\begin{array}{c}\text { Unstandardized } \\
\text { Coefficients }\end{array}$} & \multirow{2}{*}{$\begin{array}{c}\text { Standardized } \\
\text { Coefficients } \\
\text { Beta }\end{array}$} & \multirow[t]{2}{*}{$\mathrm{t}$} & \multirow[t]{2}{*}{ Sig. } & \multicolumn{2}{|c|}{$\begin{array}{c}\text { Collinearity } \\
\text { Statistics }\end{array}$} \\
\hline & B & $\begin{array}{l}\text { Std. } \\
\text { Error }\end{array}$ & & & & Tolerance & VIF \\
\hline 1 (Constant) &,- 509 & 1,026 & &,- 496 & ,620 & & \\
\hline X1 & , 160 & ,061 & ,139 & 2,642 & ,009 & ,896 & 1,116 \\
\hline $\mathrm{X} 2$ & 156 &, 067 & 131 & 2,338 & 020 & ,784 & 1,275 \\
\hline X3 & 150 & ,066 & 126 & 2,270 & 024 & 807 & 1,239 \\
\hline
\end{tabular}

Nilai t hitung untuk variabel X1 sebesar 2,642 dengan tingkat signifikansi sebesar 0,009< 0,05 sehingga Ha untuk X1 dapat diterima. Oleh karena itu, hipotesis yang menyatakan bahwa Materi Perkuliahan Kewirausahaan (X1) berpengaruh terhadap Minat berwirausaha mahasiswa(Y), dapat diterima.

Sedangkan t hitung untuk X2 sebesar 2,338 dengan tingkat signifikansi 0,020 lebih kecil dari 0,05 sehingga Ha untuk Pelatihan/Kursus Kewirausahaan (X2), dapat diterima. Oleh karena itu, hipotesis yang menyatakan bahwa variabel X2 berpengaruh terhadap Minat Mahasiswa Berwirausaha (Y), dapat diterima.

Hasil t hitung untuk Faktor Demografis (X3) sebesar 2,270 dengan tingkat signifikansi 0,024 lebih kecil dari 0,05 sehingga Ha untuk Faktor Demografis(X3) dapat diterima. Oleh karena itu, hipotesis yang menyatakan bahwa Faktor Demografis(X3) berpengaruh terhadap Minat Mahasiswa berwirausaha (Y), dapat diterima.

\section{PENUTUP}

Simpulan. Dari hasil penelitian dapat disimpulkan bahwa Materi Perkuliahan Kewirausahaani berpengaruh secara signifikan terhadap Minat Berwirausaha Mahasiswa terlihat dari nilai F hitung> nilai F tabel dan nilai Signifikan sebesar 0,000 masih di bawah $\mathrm{a}=0,05$. Minat berwirausaha mahasiswa juga dipengaruhi oleh Pelatihan/Kursus 
Kewirausahaan dan juga oleh faktor demografis seperti gender, pengalaman, dan pekerjaan orang tua.

Kemudian $\mathrm{t}$ hitung menunjukkan Nilai t hitung untuk variabel X1 sebesar 2,642 dengan tingkat signifikansi sebesar $0,009<0,05$ sehingga Ha untuk X1 dapat diterima. Dari model persamaan regresi yang telah terbentuk diperoleh nilai koefisien korelasi (Multiple R) secara menyeluruh sebesar 0,585 atau 58,5\% yang artinya hubungan antara Materi Perkuliahan Kewirausahaan (X1), Pelatihan/Kursus Kewirausahaan (X2) dan Faktor demografi (X3) sebagai variabel bebas dengan Minat Berwirausaha sebagai variabel terikat adalah positif dan cukup kuat. Jadi apabila kita ingin meningkatkan minat berwirausaha seseorang maka kita harus memperhatikan ke-3 variabel diatas.

Sedangkan nilai koefisien determinasi $\left(\mathrm{R}^{2}\right)$ adalah 0,343 . Ini berarti sebesar 34,3\% proporsi keragaman Minat Berwirausaha (Y) yang dapat dijelaskan oleh Materi Perkuliahan Kewirausahaan (X1), Pelatihan/Kursus Kewirausahaan (X2), faktor Demografis (X3), sedangkan 65,7 \% lainnya dijelaskan oleh variabel lain di luar $\mathrm{Ke}-3$ variabel bebas tersebut yang tidak diteliti dalam penelitian ini.

\section{DAFTAR RUJUKAN}

Alma, Buchari, (2006) Kewirausahaan Untuk mahasiswa dan Umum, Alfabeta, Bandung Arikunto, Suharsini, (1998) Prosedur Penelitian Suatu Pendekatan Praktek, Jakarta, PT Rineka Cipta

Ciputra, (2009) Entrepreneurship mengubah masa depan Bangsa dan masa depan Anda, Elex Media Komputindo, Jakarta, Maret.

Ciputra, (2008) Praktik Terbaik Menjadi Entrepreneur Sejati, Elex Media Komputindo, Jakarta, Desember.

Citra Sondari, Mery (2008) Hubungan antara pelaksanaan Mata Kuliah Kewirausahaan dengan Pilihan Karier Berwirausaha pada Mahasiswa dengan Mempertimbangkan Gender dan Latar Belakang Pekerjaan Orang Tua, http: //pustaka. unpad.ac.id/ wpcontent/ uploads/ 2010/06/ hubungan_antara_pelaksananan matakuliah kewirausahaan.pdf, diakses pada14/12/2014.

Eddy, Iskandar, (2006) Nyontek Kiat Bisnis 50 Entrepreneurs Sukses, Zcentral Productivity and Management Press, Karawang JawaBarat.

Fredy Rangkuti, (2002) Riset Pemasaran, Gramedia Pustaka Utama\&STIE IBII, Jakarta.

Indarti, Nurul dan Rokhima Rostiani, (2008) "Intensi Kewirausahaan Mahasiswa: Studi Perbandingan Antara Indonesia,Jepang dan Norwegia", Jurnal Ekonomika dan Bisnis Vol.23 (4) Oktober 2008,http://nurulindarti.files.wordpress.com/2009/03/ indarti-rostiani-jebi-2008.pdf, diakses pada 10 Oktober 2014.

Kotler, Philip, (2002) Manajemen Pemasaran, Edisi Milenium, Prehalindo, Yakarta.

Likert,Rensis, (1996) Organisasi Manusia: Nilai dan Manajemen, Edisi baru, Terjemahan, Penerbit Erlangga, Jakarta.

Masri Singarimbun dan Sofian Efendi, (1995) Metode Penelitian Survei, PT. Pustaka LP3ES, Jakarta.

Naresh K. Malhotra, (1996) Marketing Research: An Applied Orientatio: Prentice Hall, Inc.,Fourth Edition, Englewood Cliffs, New Jersey.

Nawawi H, Handarai, dan H. Mimin Hartini, (1994) Penilitian Terapan, Cetakan Pertama, Gadjah Mada Universitas Press, Yogyakrta. 
Singgih Santoso, (2002) Buku Latihan SPSS, Statistik Parametrik, Jakarta, Elex Media Komputindo.

Siswoyo, Bambang Banu (2009) "Pengembangan Jiwa Kewirausahaan di Kalangan Dosen dan Mahasiswa", Jurnal Ekonomi Bisnis No. 2 Tahun 14, http://fe.um.ac.id/wp-content/uploads/2009/10/bambang_banu4.pdf, diakses pada $15 / 12 / 2014$

Sugiyono, (2009) Metode Penelitian Bisnis, Alfabeta: Bandung. 